\title{
KRITIK TERHADAP ETIKA SITUASI JOSEPH FLETCHER
}

\section{Tommy Suryadi, Benyamin Fleming Intan}

Sekolah Tinggi Teologi Reformed Injili Internasional

Korespondensi: tommysuryadi@gmail.com

Korespondensi: benyaminintan@sttrii.ac.id

\begin{abstract}
ABSTRAK: Teori etika situasi Joseph Fletcher begitu berpengaruh dari sejak abad ke-20 sampai hari ini. Dampak dari pemikirannya menjangkau segala bidang termasuk etika medis serta hukum medis. Fletcher mengklaim bahwa etika situasi yang dikemukakannya bersumber dari ajaran Tuhan Yesus dan Rasul Paulus. Namun teori etika situasi tidak disetujui oleh semua kalangan dalam kekristenan termasuk kalangan Reformed. Dalam artikel ini, beberapa poin etika situasi Joseph Fletcher dalam bukunya 'Situation Ethics: The New Morality' dibahas dan dikaji menurut sudut pandang Reformed.
\end{abstract}

KATA KUNCI: etika situasi; Joseph Fletcher; kasih; Reformed.

ABSTRACT: Joseph Fletcher's theory of situational ethics is so influential since the $20^{\text {th }}$ century until this day. The fruits of his thoughts have spread to all aspects including medical ethics and medical law. Fletcher claimed that the situational ethics that he presented had its source from Lord Jesus' and Apostle Paul's teachings. But the theory of situational ethics is not agreed upon by all streams in Christianity including the Reformed stream. In this article, many points of Joseph Fletcher's situational ethics in his book 'Situation Ethics: The New Morality' are discussed and analyzed according to Reformed perspective.

KEYWORDS: situational ethics; Joseph Fletcher; love; Reformed. 


\section{Pendahuluan}

Dalam buku 'Situation Ethics: The New Morality'1, Joseph Fletcher menjelaskan pemikirannya tentang apa itu etika situasi. Secara mendasar dan secara sederhana etika situasi mengandung pengertian bahwa keputusan moral harus diambil bukan berdasarkan hukum moral yang ada tetapi berdasarkan situasi saat itu. Dalam etika ini, kasih merupakan satu-satunya norma yang dipegang. ${ }^{2}$ Norma-norma yang lain dapat dilanggar jika tindakan dalam suatu situasi tidak memenuhi hukum kasih. Di mata etika situasi, seorang suami boleh mengakhiri nyawa isterinya yang sedang sangat kesakitan dan meminta untuk dibunuh (eutanasia aktif). Ini dianggap sebagai tindakan yang memenuhi norma kasih.

Di dalam bukunya Fletcher menjelaskan enam proposisi tentang kasih: 1) Hanya ada satu hal yang baik secara intrinsik yaitu kasih, tidak ada yang lain ${ }^{3}$ 2) Norma yang berlaku dalam pembuatan keputusan Kristen adalah kasih, tidak ada yang lain ${ }^{4}$ ) kasih dan keadilan adalah sama, karena keadilan tidak lain adalah kasih yang didistribusikan ${ }^{5}$ ) Kasih menginginkan kebaikan sesama kita, entah kita menyukainya atau tidak ${ }^{6}$ ) Hanya tujuan akhir yang membenarkan cara, tidak ada yang $\operatorname{lain}^{7}$ dan 6) Keputusan kasih dibuat secara situasional, bukan secara preskriptif. ${ }^{8}$ Dalam artikel ini setiap proposisi akan dibahas dan dikaji menurut teologi Reformed.

\section{Pembahasan}

\section{Etika Situasi Bersifat Antroposentris}

Di dalam keseluruhan bukunya, Fletcher menjelaskan bahwa kaum situasionis menganut kasih yang bersifat antroposentris. Di dalam tulisan yang lain Fletcher menulis "human happiness and well-being is the highest good or summum bonum, that therefore any ends or purposes which that standard or ideal validates are just, right, good." Jadi baginya summum bonum adalah kebahagiaan manusia. Fletcher menyatakan bahwa kasih kepada Allah dinyatakan dalam bentuk melayani Allah, dan melayani Allah dalam bentuk konkritnya adalah melayani sesama. Melayani sesama, bagi Fletcher, adalah

\footnotetext{
1 Joseph F. Fletcher, Situation Ethics: The New Morality, Library of Theological Ethics (Louisville, Ky.: Westminster John Knox Press, 1997).

2 Ibid., 26.

3 Ibid., 57.

4 Ibid., 69.

5 Ibid., 87.

6 Ibid., 103.

7 Ibid., 120 .

8 Ibid., 134.

9 Fletcher, "Ethics and Euthanasia" dikutip dalam John S. Feinberg and Paul D. Feinberg, Ethics for a Brave New World, 2nd ed. (Wheaton, Ill.: Crossway, 2010), 108.
} 
satu-satunya cara bagi orang Kristen untuk mengasihi Allah. ${ }^{10}$ Pandangan Fletcher yang antroposentris ini mengkompromikan otoritas Allah yang memberikan hukum absolut dan universal. Ia juga tidak memperhitungkan kekudusan Allah karena berfokus pada manusia sehingga baginya 'sin bravely' (bagian tulisan Luther yang dikutip di luar konteksnya oleh Fletcher) adalah suatu hal yang baik. ${ }^{11}$

Hal ini bertentangan dengan teologi Reformed yang menyatakan bahwa summum bonum menurut Alkitab adalah kemuliaan Allah. Ini adalah pandangan yang bersifat teosentris. Westminster Confession of Faith menyatakan bahwa tujuan hidup manusia adalah untuk memuliakan Allah dan menikmati Dia selama-lamanya. Teologi Reformed, selain menuntut tujuan yang memuliakan Allah, juga menuntut cara memuliakan Allah yang sesuai dengan standar Alkitab dan motivasi yang berkenan di hadapan Allah-semuanya harus sesuai dengan apa yang Allah inginkan. Alkitab memberikan gambaran umat Allah sebagai hamba dan Allah sebagai Tuan. Ini berarti umat Allah tidak boleh hidup dengan tujuan, cara, dan motivasinya sendiri. Pandangan Fletcher yang antroposentris telah menggagaskan hal-hal yang tidak sesuai dengan Alkitab menurut teologi Reformed dan merelatifkan hukum Allah demi memprioritaskan kesenangan manusia.

Fletcher mengutip Markus 14:3-9 dan memberikan penjelasan berkenaan dengan bagian ini untuk membenarkan konsep utilitarianisme-nya yang bersifat antroposentris..$^{12}$ Dalam Markus 14:3-9 Yesus memuji perempuan Betania yang memprioritaskan Yesus lebih daripada manusia ketika ia memecahkan leher buli-buli untuk mencurakan minyak narwastu murni ke atas kepala Yesus. Para murid yang memprotes tindakan perempuan tersebut, menurut Fletcher, lebih benar daripada Yesus karena para murid memerhatikan kepentingan orang banyak sedangkan Yesus hanya memerhatikan kepentingan-Nya sendiri. Namun menurut Fletcher dalam kasus itu Yesus bukan sungguh-sungguh memuji perempuan itu tetapi hanya menghiburnya. Jadi bagi Fletcher bagian ini mengajarkan orang Kristen untuk lebih mengasihi manusia daripada Allah. Ini adalah tafsiran yang salah. Mengenai bagian ini Matthew Henry menulis "Tuhan Yesus kita menilai tinggi apa yang dilakukan perempuan itu... Kristus memandangnya sebagai tindakan iman yang besar, maupun sebagai kasih yang besar (ay. 8)." ${ }^{13}$ James R. Edwards menulis bahwa Yesus menempatkan diri-Nya di

\footnotetext{
Fletcher, Situation Ethics: The New Morality, 158.

Ibid., 135.

Ibid., 97.

Matthew Henry, Tafsiran Matthew Henry: Injil Markus (Surabaya: Momentum, 2007), 314.
} 
atas orang miskin dan perintah 'kasihilah sesamamu'. ${ }^{14}$ Jadi mengasihi Yesus adalah prioritas tertinggi. C. Peter Wagner menulis "Love, for Fletcher, is neighbor love. But this is only the second table of the law. The first is love of God... It is impossible for us to love our neighbor properly without first loving God, and we in turn show our love to God by obeying his commandments." 15 Di bagian lain Yesus berkata "Jikalau seorang datang kepada-Ku dan ia tidak membenci bapanya, ibunya, isterinya, anak-anaknya, saudara-saudaranya laki-laki atau perempuan, bahkan nyawanya sendiri, ia tidak dapat menjadi murid-Ku" (Lukas 14:26). Ini jelas menyatakan bahwa kasih kepada Allah harus melebihi kasih kepada manusia. Pandangan yang teosentris menuntut orang Kristen agar lebih mengasihi Allah daripada manusia.

\section{Proposisi Pertama: Only One 'Thing' is Intrinsically Good; Namely, Love: Nothing else at All}

Dalam poin ini, Fletcher menjelaskan bahwa hanya kasih yang memiliki nilai intrisik. Ini berarti hukum dan tindakan seseorang tidak memiliki nilai intrinsik. Membunuh orang yang tidak bersalah tidak memiliki nilai intrisik 'buruk' dan menjaga diri dari hubungan seks di luar pernikahan tidak memiliki nilai intrinsik 'baik'. Fletcher menyatakan bahwa nilai suatu tindakan ditentukan oleh apa dampaknya terhadap manusia. Jika membunuh orang yang tidak bersalah memberikan dampak yang baik bagi lebih banyak orang, maka tindakan tersebut adalah tindakan yang baik. Jika hubungan seks di luar nikah menghasilkan kebaikan bagi banyak orang, maka tindakan itu adalah baik adanya. Hukum tidak memiliki nilai intrinsik, maka dari itu hukum di dalam situasi tertentu bisa bersifat baik, namun di dalam situasi yang lain hukum bisa bersifat buruk. Hanya kasih yang memiliki nilai intrinsik yang baik di dalam konteks apapun bagi Fletcher.

Hal ini tidak sesuai dengan Alkitab yang juga menyatakan bahwa ada hal lain yang secara intrinsik baik selain kasih yaitu hukum. Roma 13:10 memang menyatakan bahwa kasih adalah penggenapan hukum, namun itu tidak berarti bahwa kasih adalah satu-satunya hal yang baik secara intrinsik. Dalam Roma 7:12 tertulis "Jadi hukum Taurat adalah kudus, dan perintah itu juga adalah kudus, benar dan baik." Robert Haldane membaca ayat ini dan menyatakan bahwa hukum adalah baik dari dirinya sendiri "And good. - [the law] is not only just, it is also good. It is good in itself, and its whole tendency is adapted to maintain perfect order, and to establish in the highest degree

\footnotetext{
14 James R. Edwards, The Gospel According to Mark, The Pillar New Testament Commentary (Grand Rapids, Mich: Eerdmans, 2002), 415.

15 C. Peter Wagner, "Peter Wagner-in Eternity" dalam Situation Ethics Debate. Harvey Cox (ed) (Westminster John Knox, 1968), 86.
} 
the happiness of all who are under its authority."16 1 Timotius 4:4 menyatakan "Karena semua yang diciptakan Allah itu baik dan suatupun tidak ada yang haram, jika diterima dengan ucapan syukur." Ini berarti kebaikan intrinsik juga terdapat pada semua yang diciptakan Allah. George W. Knight III menulis tentang ayat ini demikian "Paul states that the intrinsically good quality of everything created by God (cf. Gn. 1:31; Rom. 14:14, 20; Mk. 7:18, 19)."17

Dalam menjelaskan proposisi pertama ini, Fletcher juga menulis "only malice is intrinsically evil. If goodwill is the only thing we are always obliged to do, then ill will is the only thing we are always forbidden to do." ${ }^{18}$ Jika hanya kasih yang secara intrinsik adalah baik, maka, menurut Fletcher, 'malice' adalah satu-satunya hal yang memiliki nilai intrinsik yang buruk. Namun Alkitab telah menyatakan bahwa hukum secara intrinsik adalah baik, maka 'lawlessness' secara intrinsik adalah buruk. Alkitab juga menyatakan bahwa dosa secara intrinsik adalah buruk karena dosa merupakan perlawanan terhadap Allah dan melawan Allah pasti adalah buruk apapun konteksnya. 1 Yohanes 3:4 menyatakan "Setiap orang yang berbuat dosa, melanggar juga hukum Allah, sebab dosa ialah pelanggaran hukum Allah."

\section{Proposisi Kedua: The Ruling Norm of Christian Decision is Love: Nothing else}

Etika situasi mereduksi seluruh hukum atau sistem hukum menjadi kanon kasih semata. Fletcher beranggapan bahwa Yesus dan Paulus tanpa ragu mengabaikan hukum Allah (selain kasih) demi hukum kasih. Ia mengutip Markus 2:27-28, 1 Korintus 10:23-26, dan 2 Korintus 3:6 untuk menyatakan bahwa Yesus dan Paulus mengabaikan hukum demi kasih. ${ }^{19}$ Namun ini jelas adalah pembacaan yang salah terhadap Yesus dan Paulus yang jelas menilai hukum sebagai hal yang baik yang diberikan oleh Allah. Fletcher melihat bahwa Matius 22:37 menjadi penyaring bagi semua hukum lainnya, namun ini adalah tafsiran yang salah. Ini karena Fletcher memiliki presuposisi bahwa hukum dan kasih adalah dua hal yang dapat berkonflik dalam situasi-situasi tertentu. Baginya hukum dapat diabaikan jika tidak mementingkan kasih. John Jefferson Davis tidak setuju dengan pandangan ini. Baginya hukum ilahi Allah tidak boleh dikompromikan. Ia menulis "Apart from the abiding norms of divine revelation, the moral agent is left to the vagaries of personal preference and the constantly changing 'spirit of the age' to discern the 289.

16 Robert Haldane, Exposition of the Epistle to the Romans (Edinburgh: The Banner of Truth Trust, 1996),

George W. Knight III, NIGTC: The Pastoral Epistles (Grand Rapids, Michigan: Eerdmans, 1996), 191.

8 Fletcher, Situation Ethics: The New Morality, 63.

19 Ibid., 71. 
'loving' thing." 20 Namun ketika dua hukum ilahi menjadi bertentangan dalam suatu situasi, penulis berpandangan bahwa hukum yang lebih besar atau lebih utama yang harus dilaksanakan (pandangan absolutisme bertingkat). ${ }^{21}$

John Frame melihat bahwa kasih sebagai salah satu dari sekian banyak perintah ${ }^{22}$, tidak seperti Fletcher yang melihat kasih bukan sebagai perintah tetapi maxim. Frame menyatakan bahwa Fletcher tentu saja ingin menyatakan bahwa kasih bukanlah peraturan atau hukum karena ia tidak ingin manusia hidup di bawah hukum. ${ }^{23}$ Frame menyatakan bahwa jika hanya kasih yang selalu baik, maka sulit untuk mengerti mengapa kasih bukan merupakan hukum atau peraturan. Oleh karena itu, Fletcher menyangkal keberadaan hukum dan ia menerima hukum yang tidak dapat didefinisikan. Bagi Frame ini adalah suatu hal yang irasional. Frame juga menegaskan bahwa Alkitab jelas menyatakan bahwa kasih adalah perintah Allah. Dalam Ulangan 6:1-5 tertulis “Inilah perintah, yakni ketetapan dan peraturan, yang aku ajarkan kepadamu atas perintah TUHAN, Allahmu, untuk dilakukan di negeri, ke mana kamu pergi untuk mendudukinya... Kasihilah TUHAN, Allahmu, dengan segenap hatimu dan dengan segenap jiwamu dan dengan segenap kekuatanmu." Mengenai bagian ini Frame menulis "That fact immediately rules out any opposition or antithesis between love and commandments in general. Any arguments directed against the keeping of commandments in general carry equal weight against the keeping of the love commandment specifically." 24

Frame juga menulis bahwa umat Kristen mendemonstrasikan kasih dengan cara mentaati perintah Allah dan untuk mengasihi Allah secara total berarti memperhatikan Firman-Nya. Ia menulis "We demonstrate out love by obeying the commandments... To love God completely is to take heed to his words... This is certainly at least part of what is meant by love fulfilling the law: love carries out the commandments of the Lord." ${ }^{25}$ Ini, bagi Frame, adalah sesedikitnya sebagian dari apa artinya 'kasih menggenapi hukum'; kasih melaksanakan perintah-perintah Allah. Salah satu tema besar dalam tulisan-tulisan Yohanes ${ }^{26}$ adalah mengasihi Yesus dengan menaati semua perintah-Nya. Hukum Allah memerintahkan umat-Nya untuk mengasihi dan hukum kasih menuntut umat Allah untuk menaati segala perintah-Nya. Ini berbeda dengan pandangan Fletcher yang menyatakan bahwa seseorang

20 John Jefferson Davis, Evangelical Ethics: Issues facing the Church Today (P\&R, 1993), 6.

21 Norman Geisler menulis "graded absolutism holds that when moral laws conflict, God grants an exemption to the lower law in view of our duty to obey the higher law". Norman Geisler, Christian Ethics: Contemporary Issues $\mathcal{E}$ Options $2^{\text {nd }}$ Edition (Grand Rapids: Baker Academic, 2010), 20.

22 John Frame, The Doctrine of the Christian Life (Phillipsburg: P\&R Publishing, 2008), 193.

23 Ibid., 194.

24 Ibid., 194-5.

25 Ibid., 195.

26 Yohanes 13:34-35, 14:15, 14:21; 1 Yohanes 2:5, 3:10, 3:18, 3:23; 2 Yohanes 1:5, 1:6 
harus melanggar perintah ilahi untuk memenuhi hukum kasih. ${ }^{27}$

Hukum dan kasih bagi Frame memiliki konten yang sama namun dilihat dari dua sudut yang berbeda. ${ }^{28}$ Perbedaan keduanya terletak pada fokus atau penekanannya. Hukum berfokus pada tindakan yang harus dilakukan dan kasih berfokus pada motivasi dari tindakan tersebut. Menurut Frame, Hal ini bertentangan dengan konsep slavish obedience (Kant's 'duty for duty's sake') dan kebaikan menurut Plato (kasih sebagai konsep yang abstrak dan kosong).

\section{Proposisi Ketiga: Love and Justice are the Same, For Justice is Love Distributed, Nothing else}

Bagi Fletcher kasih adalah keadilan dan keadilan adalah kasih. Ia sama sekali tidak memisahkan kedua hal ini. Bagi Fletcher kasih adalah keadilan seperti iman adalah perbuatan dan juga sebaliknya. Ia menulis:

Some theologies treat faith-works as faith versus works, some as faith or works, some as faith and works. Christian situation ethics says faith is works, i.e., simply put, that faith works. In the same way various systems of Christian ethics have related love and justice: love versus justice (opposites), love or justice (alternatives), love and justice (complements). We say, however, very positively, that love is justice or that justice loves. They are one and the same. To be loving is to be just, to be just is to be loving..$^{29}$

Namun Alkitab dengan jelas menyatakan bahwa iman bukanlah perbuatan dan sebaliknya, tetapi tetap menyatakan bahwa dua hal tersebut memiliki hubungan satu sama lain. Dalam Efesus 2:8-9 tertulis "Sebab karena kasih karunia kamu diselamatkan oleh iman; itu bukan hasil usahamu, tetapi pemberian Allah, itu bukan hasil pekerjaanmu: jangan ada orang yang memegahkan diri." Dalam bagian ini Paulus menyatakan bahwa umat Allah diselamatkan oleh iman dan bukan perbuatan. Jika iman adalah perbuatan seperti yang Fletcher katakan, maka Paulus menyatakan "kamu diselamatkan oleh iman; itu bukan hasil imanmu." Pernyataan ini mengandung kontradiksi. Demikian pula, menurut penulis, kasih tidak dapat disamakan dengan keadilan seperti iman tidak dapat disamakan dengan perbuatan. Seorang hakim dapat memberikan keadilan kepada seorang pembunuh tanpa harus mengasihinya. Ahli-ahli Taurat dan orang-orang Farisi tahu mengenai keadilan tetapi tidak melakukannya dengan niat kasih (Yoh. 8:2-11).

\footnotetext{
27 Fletcher, Situation Ethics: The New Morality, 71.

8 Frame, The Doctrine of the Christian Life, 196.

29 Fletcher, Situation Ethics: The New Morality, 93.
} 
Fletcher juga menyatakan bahwa kasih dan kebijaksanaan (prudence) adalah sama "Prudence and love are not just partners, they are one and the same. That is to say, Christian love and Christian prudence are one and the same, since they both go out to others." Kebijaksanaan juga mendukung kasih "Prudence, careful calculation, gives love the care-fulness it needs; with proper care, love does more than take justice into account, it becomes justice." ${ }^{30}$ Jika demikian maka keadilan adalah kebijaksanaan dan juga sebaliknya. Namun sebelumnya Fletcher juga menyatakan bahwa 1) keadilan adalah kasih yang didistribusikan, 2) keadilan adalah berbagai sisi dari kasih, dan 3) keadilan adalah kasih Kristen yang memperhitungkan tugas, peluang, dan sumber dayanya. Di bagian lain juga Fletcher menyatakan bahwa kasih adalah kebajikan (benevolence) dan juga niat baik (goodwill). Penjelasan Fletcher dalam hal ini membuat ambiguitas karena tidak membedakan lima hal (kasih, keadilan, kebijaksanaan, kebajikan, dan niat baik) yang jelas berbeda.

Fletcher menyatakan kesulitan dalam mendistribusikan kasih "How are its favors to be distributed among so many beneficiaries? We never have one neighbor at a time... Even if we define justice as giving to others what is their due, we must redefine it Christianly." 31 Jawaban Fletcher bagi permasalahan ini adalah "There is no partiality, no 'respecting of persons,' in preferring to serve more rather than fewer, many rather than few. Love must make estimates; it is preferential. That is to say, it is responsible, thoughtful, careful." ${ }^{32}$ Jadi Fletcher memandang bahwa mayoritas harus lebih dipentingkan daripada minoritas. Pandangan ini dikritik oleh Glen Harold Stassen dan David P. Gushee:

[Fletcher's] utilitarian version of teleology has the problem of lacking any principle of just distribution that guards the rights of the minority. If we are to do whatever is best for the welfare of the greatest number, we have no basis for guarding minority rights. Teleological ethics can justify manipulating the truth, killing enemies and stifling minority religions or minority races if that is the most efficient way to advance the good consequences one seeks. A not very good example is John 11:50-53, where Caiaphas the high priest argues that "it is expedient for you that one man should die for the people, and that the whole nation should not perish... So from that day on they took counsel how to put him to death. ${ }^{33}$

Berdasarkan apa yang Stassen dan Gushee katakan, dapat disimpulkan bahwa Fletcher setuju dengan keputusan Kayafas yang memilih untuk mengorbankan Yesus demi rakyat dan dengan keputusan Pilatus yang

$30 \quad$ lbid., 88.

31 Ibid., 88-89.

32 Ibid., 98.

33 Glen Harold Stassen and David P. Gushee, Kingdom Ethics: Following Jesus in Contemporary Context (Downers Grove, Ill.: InterVarsity Press, 2003), 119. 
menyerahkan Yesus untuk disalib demi memuaskan permintaan mayoritas. Jika pandangan Fletcher tentang distribusi kasih ini diterapkan oleh pemerintah di Indonesia, maka para penganut agama-agama non-Islam tidak akan pernah mendapatkan 'kasih' dari pemerintah.

\section{Proposisi Keempat: Love Wills the Neighbor's Good Whether We Like Him or Not}

Fletcher menyatakan bahwa mengasihi secara kristiani adalah masalah sikap dan bukan perasaan. ${ }^{34}$ Ia juga mengutip Soren Kierkegaard "to say that love is a feeling or anything of that kind is an unchristian conception of love." ${ }^{35}$ Bagi Fletcher, jika kasih merupakan perasaan maka tidak mungkin kasih dapat diperintahkan karena hanya akan menciptakan kemunafikan. Orang Kristen dapat mengasihi karena perintah mengasihi, bagi Fletcher, bukanlah mengenai perasaan. Ia menulis "loving and liking are not the same thing" dan "there can be no command, no obligation, no duty, to love if love is affection." ${ }^{36}$ Kasih dianggap seperti aspek-aspek lain dari buah Roh yang dapat diperintahkan karena mereka bukan mengenai perasaan.

Pandangan Fletcher dalam bagian ini juga bertentangan dengan teologi Reformed. Frame menulis tentang kasih:

We may think of it triperspectivally: love is allegiance, action, and affection. Within the covenant, love describes the exclusive allegiance of the vassal to the suzerain. Scripture also defines love by action, as by Jesus' atoning work in 1 John 4:10 and our actions toward others in Romans 13:10 and Ephesians $5: 2$. Biblical love is also affection, as indicated by references to romantic and sexual love (Gen. 29:20, 32; Prov. 5:19), the analogy therein to God's love (Hos. 3:1; 11:4; 14:4; Zeph. 3:17), close friendship (Ps. 119:97) and for other believers (Rom. 12:10; 1 Peter 1:22; 1 John 3:17). ${ }^{37}$

Paulus menjelaskan bahwa kasih memiliki aspek perasaan yaitu sukacita. Ia menulis bahwa kasih bersukacita karena kebenaran (1 Korintus 13:6) dan sukacita juga merupakan salah satu aspek dari buah Roh. Allah memerintahkan umat-Nya untuk mengasihi-Nya dengan segenap hati mereka (Matius 22:37). Ini berarti kasih kepada Allah harus mencakup perasaan. Jika kasih eksklusif seorang Kristen kepada Allah ada di dalam seluruh keberadaan orang itu dari hati, seperti yang dinyatakan Ulangan 6, maka kasih tersebut ada dalam seluruh aspek hidup orang itu: perasaan, kehendak, dan rasio. Jadi tidak mungkin seseorang dapat mengasihi dengan

\footnotetext{
Fletcher, Situation Ethics: The New Morality, 103.

Ibid., 104.

Ibid., 106.

Frame, The Doctrine of the Christian Life, 193.
} 
seluruhnya jika tidak melibatkan perasaan juga. Berkali-kali dalam Alkitab dinyatakan bahwa Allah bisa cemburu (Keluaran 20:5; 34:14, Bilangan 25:11, Ulangan 4:24; 5:9; 6:15; 29:20; 32:16; 32:21, Yosua 24:19, dan lainnya). Pemazmur menyatakan dirinya mendambakan (desire) Allah (Mazmur 73:25). Yesus menangis saat akan membangkitkan Lazarus (Yohanes 11:3536). Allah adalah Pribadi, maka adalah tidak mungkin jika manusia berelasi dengan sesamanya dan Pribadi Allah tanpa melibatkan perasaan.

Fletcher juga menyatakan bahwa semua orang tanpa terkecuali adalah 'sesama', maka kasih harus diberikan kepada semua orang. Baginya, 'musuh' juga masuk dalam kategori 'sesama', atau 'musuh' diakui sebagai salah satu jenis 'sesama'. Ia menulis "It does not seek the deserving, nor is it judgmental when it makes its decisions-jugdmental, that is, about the people it wants to serve" 38 dan "Christian love is the business of loving the unlovable, i.e., the unlikeable."

Bagi Frame, Alkitab tidak menyatakan demikian. Alkitab membedakan 'sesama' dengan 'musuh'. Baginya, Alkitab tidak mengajarkan bahwa semua orang adalah sesama. Ia menulis bahwa tidak semua orang yang ditemui di jalan adalah orang yang membutuhkan pertolongan. Orang yang berada di jalan mungkin saja adalah seorang perampok atau pembunuh yang dapat dikategorikan sebagai musuh. ${ }^{39}$ Yesus mengajarkan umat-Nya untuk mengasihi musuh (Matius 5:43-48). Jika semua orang dianggap sebagai sesama oleh Alkitab, maka seharusnya tidak ada orang yang dianggap sebagai musuh. Jika tidak ada orang yang disebut musuh, maka Yesus tidak mungkin dapat mengajarkan 'kasihilah musuhmu' dan ahli Taurat itu tidak perlu bertanya 'siapakah sesamaku manusia?' (Lukas 10:29). Alkitab menyatakan bahwa Allah pun mengasihi musuh-musuh-Nya. Dalam Matius 5:43-48 Yesus berkata bahwa Allah memberikan musuh-musuh-Nya pemberian yang baik untuk mereka. Musuh-musuh Allah mencakup mereka yang belum bertobat dan mereka yang tidak dipilih. Dalam Perjanjian Lama, beberapa suku dari bangsa Kanaan adalah musuh Allah yang harus dibasmi oleh bangsa Israel.

\section{Proposisi Kelima: Only the End Justifies the Means; Nothing else}

Bagi Fletcher, mengatakan tujuan tidak dapat menghalalkan cara adalah sama dengan berkata "a thing is not worth what it costs, that nothing is, that use or usefulness is irrelevant to price." ${ }^{\prime 4}$ Fletcher menyatakan bahwa tidak ada yang dapat membenarkan cara jika bukan tujuan. Semua tindakan tidak

\footnotetext{
38 Fletcher, Situation Ethics: The New Morality, 105.

39 Frame, The Doctrine of the Christian Life, 836.

40 Fletcher, Situation Ethics: The New Morality, 120.
} 
ada artinya jika tidak mentargetkan suatu tujuan. Arti dari suatu tindakan ada jika tindakan tersebut melayani suatu tujuan. Fletcher menulis "means without ends are empty and ends without means are blind. They are relative to each other. In any course of action it is the coexistence of its means and ends that puts it in the realm of ethics." ${ }^{\prime 1}$ Namun baginya tidak semua tujuan dapat membenarkan semua cara. Tujuan harus dikalkulasi dengan sebaik mungkin sehingga dapat menghasilkan kebaikan yang lebih besar dan/atau lebih luas. Segala cara yang dipakai harus benar-benar dipastikan dapat memenuhi tujuan yang diinginkan. Fletcher menulis "the means used ought to fit the end, ought to be fitting. If they are, they are justified." 42

Fletcher menyatakan bahwa seandainya tujuan tidak membenarkan cara, maka tidak ada yang dapat membenarkan cara. Ini tidak sesuai dengan teologi Reformed. Frame menyatakan bahwa ada tiga syarat agar suatu perbuatan dapat dinilai baik di mata Allah: motivasi yang benar, ketaatan terhadap hukum Allah, dan tujuan yang benar yaitu memuliakan Allah. ${ }^{43}$ Jika satu syarat saja tidak terpenuhi maka perbuatan tersebut tidak dapat dinilai baik.

Fletcher hanya memberikan satu syarat untuk perbuatan baik yaitu tujuan kasih. Kasih dapat membenarkan apapun di mata Fletcher. Perspektif ini bagi Childress telah mempresuposisikan kapasitas manusia yang seperti Allah sehingga dapat menentukan dan mengendalikan hasil dari suatu tindakan. Ia menulis "This perspective appears to presuppose a greater capacity to predict and control outcomes of action than human beings actually have. Someone once suggested that God might be utilitarian, but that we can't, because we lack omniscience and power over actions and outcomes." ${ }^{44}$ Hollinger menyatakan bahwa dari aspek praktika, utilitarianisme berasumsi bahwa manusia dapat menimbang konsekuensi dari suatu tindakan secara obyektif. Asumsi ini bermasalah karena pertimbangan yang dihasilkan bisa sangat beragam dari berbagai orang. Ia menulis "From a practical standpoint, utilitarianism assumes that we can objectively weigh the consequences of a given course of action. But this is highly debatable, for often our biggest differences in ethics are over the empirical or factual judgments surrounding an issue, and those differences only increase when we attempt to assess consequences." ${ }^{45}$

41 Ibid., 121.

42 Ibid., 122.

43 Frame, The Doctrine of the Christian Life, 28.

44 James F. Childress, "Introduction" dalam Situation Ethics: The New Morality, Library of Theological Ethics (Louisville, Ky.: Westminster John Knox Press, 1997), 8.

45 Dennis P. Hollinger, Choosing the Good: Christian Ethics in a Complex World (Grand Rapids, Mich.: Baker Academic, 2002), 34-35. 
Alkitab tidak pernah menyatakan bahwa umat Allah boleh melanggar perintah Allah demi mencapai tujuan yang baik. Alkitab justru mengutuk mereka yang berbuat demikian. Saul dihakimi oleh Tuhan karena tidak mematuhi perintah Allah meskipun ia berniat untuk memberikan korban bagi Allah (1 Samuel 15). Uza dimatikan oleh Tuhan karena menyentuh tabut perjanjian meskipun ia sebenarnya berniat baik (2 Samuel 6:5-7). Mengenai bagian ini Richard L. Pratt Jr. menulis "Uzzah reached out his hand to steady the ark. The text offers no indication that Uzzah acted with evil intent. Nevertheless, God became angry and struck him down... Although Moses' Law warned that no human hand was to touch the ark, Uzzah did not restrain himself." 46 Tujuan yang baik tidak dapat menghalalkan cara yang salah di mata Allah. Pelanggaran terhadap hukum Allah, meskipun dilakukan dengan tujuan yang baik, tetap mendapatkan penghakiman dari Allah. Roma 3:5-8 menyatakan bahwa pelaku dosa tidak dapat dibenarkan meskipun ada hal yang baik timbul dari perbuatan jahatnya. John Calvin menyatakan bahwa kejahatan tidak mungkin menghasilkan sesuatu selain kejahatan dan kemuliaan Allah melalui dosa manusia bukanlah karya manusia tetapi pekerjaan Allah. Ia menulis "That evil cannot of itself produce any thing but evil; and that God's glory is through our sin illustrated, is not the work of man, but the work of God." 47

F. Godet menyatakan bahwa argumen yang menyatakan bahwa tujuan yang baik menghalalkan cara yang jahat sering dipakai untuk membenarkan kejahatan-kejahatan yang besar di dalam sejarah dengan menyatakan bahwa kejahatan-kejahatan tersebut telah memberikan kontribusi yang positif bagi kemanusiaan. ${ }^{48}$ Tidak ada seorang pun dari penjahat-penjahat tersebut yang menjadi orang suci karena utilitarianisme. Godet menyatakan pengajaran utilitarianisme adalah sesuai dengan panteisme karena manusia tidak dapat lagi diminta pertanggungjawabannya dan penghakiman tidak lagi bermakna. Tanpa aturan yang menjadi standar, penghakiman tidak mungkin dilakukan. Kekacauan tidak dapat terelakan ketika setiap orang berbuat apa yang benar menurut pandangannya sendiri (Hakim-Hakim 17:6).

\section{Proposisi Keenam: Love's Decisions are Made Situationally, Not Prescriptively}

Fletcher berpendapat bahwa terlalu banyak orang menginginkan suatu sistem etika yang memberikan suatu arahan yang jelas mengenai moralitas

\footnotetext{
46 Richard L. Pratt, 1 and 2 Chronicles, Mentor Commentary (Fearn, Ross-shire: Mentor, 1998), 129.

47 John Calvin, Commentaries on the Epistle of Paul the Apostle to the Romans (Grand Rapids, Mich: Eerdmans, 1947), 122.

48 F. Godet, Commentary on St. Paul's Epistle to the Romans, terj. A. Cusin (Edinburgh: T. \& T. Clark), vol. 1, 233 .
} 
dari segala hal. Ia menulis "They want to lean on strong, unyielding rules... People like to wallow or cower in the security of the law. They cannot trust themselves too much to the freedom of grace; they prefer the comfortableness of law." ${ }^{49}$ Ini berbeda dengan kaum situasionis yang melepaskan dirinya dari "the dead hand of unyielding law, with its false promises of relief from the anguish of decision." ${ }^{50}$ Fletcher menyatakan kaum situasionis sebagai orang yang bebas "His moral life takes on the shape of adventure, ceases to pretend to be a blueprint." Fletcher juga memuji kerendahan hati kaum situationis "In all humility, knowing that he cannot escape the human margin of error, he will-in Luther's apposite phrase-sin bravely."

Fletcher tidak mengakui hukum preskriptif yang memimpin kehidupan manusia. Baginya hukum adalah rantai yang mengikat kebebasan manusia. Manusia diperbudak oleh hukum dan harus dibebaskan dengan hidup tanpa hukum (kecuali kasih). Ini membawa para kaum situasionis kembali ke zaman para hakim di masa Perjanjian Lama dimana semua orang berbuat apa yang baik menurut pemikirannya sendiri. Fletcher mengira bahwa Paulus ingin supaya orang Kristen tidak lagi hidup dengan hukum, namun sebenarnya Alkitab tidak pernah berkata demikian. Paulus menyatakan bahwa manusia diselamatkan bukan karena melakukan hukum, namun manusia yang sudah diselamatkan dituntut untuk melakukan perintah Allah (Efesus 2:8-10).

Fletcher menyatakan bahwa kaum situasionis hidup sebagai manusia yang bebas dengan segala ambiguitas yang dapat muncul dalam kebebasan tersebut. Baginya kaum situasionis dengan rendah hati mengetahui bahwa ia tidak mungkin lepas dari kesalahan sama sekali dan hidup 'berdosa dengan berani' seperti yang Luther katakan. Ada sebuah kontradiksi yang Fletcher katakan. Ia menyatakan bahwa kaum situasionis hidup dengan bebas, namun ia juga menyatakan bahwa mereka tidak bisa lepas dari kesalahan. Fletcher mengakui bahwa kaum situationis hidup dalam ambiguitas - seperti yang terjadi dalam zaman para hakim Perjanjian Lama. Ia juga mengutip kalimat Luther dengan melepaskan dari konteksnya. Tulisan Luther yang lebih lengkap berbunyi demikian:

If you are a preacher of mercy, do not preach an imaginary but the true mercy. If the mercy is true, you must therefore bear the true, not an imaginary sin. God does not save those who are only imaginary sinners. Be a sinner, and let your sins be strong (or "Sin boldly"), but let your trust in Christ be stronger, and rejoice in Christ who is the victor over sin, death, and the world. We will commit sins while we are here, for this life is not a place where justice resides.

49 Fletcher, Situation Ethics: The New Morality, 134.

50 Ibid., 135. 
We, however, says Peter (2 Peter 3:13) are looking forward to a new heaven and a new earth where justice will reign. It suffices that through God's glory we have recognized the Lamb who takes away the sin of the world. No sin can separate us from Him, even if we were to kill or commit adultery thousands of times each day. Do you think such an exalted Lamb paid merely a small price with a meager sacrifice for our sins? Pray hard for you are quite a sinner.

Kalimat ini merupakan bagian dari surat Luther kepada Philip Melanchthon. Berkenaan dengan bagian ini, penulis setuju dengan Erick Sorensen ${ }^{51}$ yang menulis:

Luther was writing to his main partner in the Reformation, Philip Melanchthon, seeking to encourage him. It seems Philip had become quite full of despair over a number of things, one of those things being his own struggles with sin. So, after writing 11 paragraphs in response, addressing many problems, Luther wrote this to his old friend... It's clear that what Luther is saying here is not to go sin so that grace will abound (Romans 6:1). Rather he's advocating brutal honesty and forthrightness before God, not being afraid to call a thing what it is..$^{52}$

Masalah-masalah dalam kehidupan tidak selalu dapat dinilai secara jelas hitam atau putih-tidak sedikit yang berada dalam area abu-abu. Fletcher menulis "So many decisions in life are of this kind; they fall in between... This is where the call to sin bravely is sharpest." ${ }^{33}$ Fletcher memberikan pujian kepada wanita hamil yang memutuskan untuk mengugurkan kandungannya karena bayinya berpotensi untuk tumbuh menjadi anak yang cacat "It was a brave and responsible and right decision, even if the embryo had been all right. It was a kairos, a fullness of time, a moment of decision." Pada tahun 1841, Holmes membunuh setengah dari penghuni kapal yang kelebihan muat agar kapal itu tidak tenggelam dan seluruh penumpang meninggal. Kaum legalis mengutuk tindakan Holmes, namun Fletcher memujinya karena ia berdosa secara berani..$^{54}$

Fletcher menyatakan bahwa di dalam hidup manusia akan menghadapi situasi abu-abu (grey area). Area abu-abu ini akan terus meluas karena hidup dan kebudayaan dalam perkembangan teknologi terus bertumbuh dan menjadi semakin kompleks. Bagi Fletcher kaum legalis tidak mungkin dapat berkembang lebih cepat dari perkembangan kompleksitas yang ada. Di dalam kompleksitas yang bertumbuh ini Fletcher melihat panggilan untuk 'berdosa dengan berani' semakin kuat. Fletcher tidak konsisten karena

51 Erick Sorensen adalah seorang hamba Tuhan senior yang pernah studi di Lutheran Brethren Bible College dan Lutheran Brethren Seminary.

52 Erick Sorensen, Sin Boldly?, https://www.1517.org/articles/sin-boldly (diakses: 14/04/2018).

53 Fletcher, Situation Ethics: The New Morality, 135.

54 Ibid., 136. 
di satu bagian ia menyatakan bahwa tidak ada hukum atau standar absolut selain kasih namun di satu sisi ia menyatakan bahwa ada hitam, putih, dan area abu-abu yang besar. Jika Fletcher sungguh tidak menganut standar apapun selain kasih yang dijelaskannya secara abstrak, maka ia tidak mungkin dapat memilah antara area hitam, putih, dan abu-abu.

Alkitab, berlawanan dengan pandangan Fletcher, memanggil umat Allah untuk pergi menjauhi dosa (Yohanes 5:14). Meskipun Alkitab tidak mendeskripsikan setiap situasi yang mungkin ditemui di dalam kehidupan sehari-hari dan tidak memberikan norma bagi semua situasi secara spesifik, Alkitab memberikan norma-norma umum yang merupakan prinsip bagi orang Kristen untuk diaplikasikan di dalam setiap situasi. Seperti yang dikatakan Frame, penulis percaya bahwa Alkitab mengandung semua perkataan ilahi yang dibutuhkan dalam segala aspek hidup manusia. ${ }^{55}$ Ia menyatakan bahwa Alkitab berbicara mengenai segala sesuatu secara implisit. Frame menulis bahwa Alkitab itu cukup dalam memberikan panduan etika Kristen:

Certainly Scripture contains more specific information relevant to theology than to dentistry, and so forth. But sufficiency in the present context is not sufficiency of specific information but sufficiency of divine words. Scripture contains divine words sufficient for all of life. It has all the divine words that the plumber needs, and all the divine words that the theologian needs. So it is just as sufficient for plumbing as it is for theology. And in that sense it is sufficient for science and ethics as well. ${ }^{56}$

Alkitab cukup dalam memberikan pengajaran dan juga hal-hal yang dapat dideduksi secara logis dari pengajaran tersebut. Selama deduksi logis yang dihasilkan adalah benar dan sesuai dengan pengajaran Alkitab, maka otoritas implikasi logis tersebut adalah sama dengan otoritas Alkitab dan deduksi logis tersebut tidak menambahkan isi Alkitab. Davis menulis "human reason has a legitimate role in extending the general principles of Scripture to analogous circumstances not explicitly addressed in the canonical texts." ${ }^{57}$

Tugas orang Kristen adalah mempelajari apa yang Alkitab katakan dan menggunakan wahyu umum untuk membuat keputusan yang berkenan pada Allah. Frame menyadari ini bukanlah hal yang mudah, namun ia menyatakan bahwa Allah selalu hadir untuk menuntun umat-Nya. Jadi wahyu umum tetap memiliki peran dan penting dalam memberikan panduan. Misalnya, Alkitab tidak berbicara secara khusus mengenai aborsi, namun wahyu umum menyatakan kepada orang Kristen bahwa aborsi adalah tindakan mengambil nyawa orang yang tidak bersalah. Oleh sebab

\footnotetext{
Frame, The Doctrine of the Christian Life, 156.

Ibid., 157.

Davis, Evangelical Ethics: Issues facing the Church Today, 5.
} 
itu aborsi bisa dianggap sebagai tindakan pembunuhan, dan Alkitab berbicara mengenai pembunuhan.

Aborsi, sebagai pilihan terakhir, boleh dilakukan dalam kasus tertentu misalnya jika kehamilan membahayakan nyawa ibu dan bayi. Dalam kasus tersebut, jika kehamilan tersebut dibiarkan maka keduanya (ibu dan bayi) akan sangat mungkin meninggal. Jika aborsi dilakukan, maka nyawa ibu bisa diselamatkan. Jadi aborsi maupun tidak, dalam kasus ini nyawa bayi memang tidak dapat diselamatkan. Aborsi dalam kasus ini dibenarkan karena berhubungan dengan masalah hidup atau mati (absolutisme bertingkat), tidak seperti pandangan Fletcher di mana aborsi dibenarkan hanya karena ibu tidak menginginkan bayi tersebut (misalnya karena ada kecacatan).

\section{Kesimpulan}

Karya tulis Fletcher 'Situation Ethics' memberikan suatu kontribusi yang besar dalam mengajak para pembacanya untuk merenungkan kembali pengertian tentang kasih secara mendalam. Bagi penulis, Fletcher sudah tepat dalam memberikan penekanan yang besar pada kasih dan dalam menempatkan kasih sebagai yang terutama. Namun beberapa bagian dari pengertian Fletcher tentang kasih tidak sesuai dengan pandangan Alkitab menurut teologi Reformed. Fletcher menyatakan bahwa etika situasi yang dikemukakannya adalah sesuai dengan ajaran Yesus dan Paulus. Namun ayat-ayat Perjanjian Baru yang dikutipnya (Fletcher sangat jarang mengutip ayat Perjanjian Lama untuk mendukung teorinya) telah ditafsirkannya secara salah dan digunakannya untuk mendukung teorinya. Fletcher tidak mengutip cukup banyak ayat Alkitab untuk mendukung teori etika situasinya sebagai teori yang diklaimnya sesuai ajaran Tuhan. Ia juga tidak melakukan eksegesis yang cukup dalam dan bertanggung jawab terhadap ayat-ayat, yang jumlahnya relatif sedikit, yang dikutipnya. Ia mengabaikan hukum sama sekali dan hanya melihat kasih agape sebagai satu-satunya nilai yang absolut - suatu pernyataan yang bersifat sangat reduktif. Baginya ini sesuai dengan ajaran Yesus dan Paulus. Ia juga mengutip secara tidak lengkap pernyataan Luther dan mengajak para pembacanya untuk berdosa secara berani.

Ia memberikan enam proposisi mengenai kasih, namun ia sendiri tidak pernah menjelaskan atau menyebutkan secara eksplisit apakah proposisi-proposisi ini bersifat absolut atau relatif. Dalam proposisi kedua ia menyebutkan bahwa kasih sajalah yang absolut dan bahwa kasih adalah norma satu-satunya. Implikasi logis dari pernyataannya adalah teori etika situasi yang ditulisnya dalam buku 'Situation Ethics: The New Morality' 
memiliki sifat relatif. Fletcher juga menciptakan suatu ambiguitas karena ia menyamakan kasih dengan keadilan dan juga dengan kebijaksanaan. Fletcher juga menolak adanya hukum preskriptif dan menjunjung tinggi kebebasan. Ia sendiri mengakui bahwa kaum situasionis hidup dalam ambiguitas dan bahwa mereka harus 'sin bravely'. Kasih agape bagi Fletcher tidak mengandung afeksi, namun jelas bahwa Alkitab menyatakan bahwa Allah yang memberikan kasih agape kepada umat-Nya bukanlah Allah tanpa afeksi.

Satu hal yang sangat kurang diperhitungkan oleh Fletcher dalam bukunya adalah topik tentang kekudusan. Ini karena Fletcher memikirkan etika yang bersifat antroposentris dan bukan teosentris. Petrus menulis "Hendaklah kamu menjadi kudus di dalam seluruh hidupmu sama seperti Dia yang kudus, yang telah memanggil kamu, sebab ada tertulis: Kuduslah kamu, sebab Aku kudus" (1 Petrus 1:15-16). Topik tentang kekudusan dibicarakan dan tetap berlaku dalam Perjanjian Baru. Alkitab menyatakan bahwa Allah melalui suku Lewi membunuh tiga ribu orang dari bangsa Israel karena mereka membuat dan menyembah patung berhala (Keluaran 32:28). Nadab dan Abihu dihukum mati oleh Tuhan karena mereka mempersembahkan api yang asing yang tidak sesuai ketetapan Tuhan (Imamat 10:2).

Dalam Perjanjian Baru juga dinyatakan bahwa Tuhan menghakimi mereka yang meremehkan kekudusan Allah. Ananias dan Safira mendustai Roh Kudus dan mereka mati seketika (Kisah Para Rasul 5:3-10). Simon si penyihir ingin membeli karunia Allah dengan uang sehingga ia pasti mati jika ia tidak bertobat (Kisah Para Rasul 8:20-24). Semua contoh ini, termasuk yang lainnya yang tidak disebutkan, menunjukkan bahwa Allah menganggap serius kekudusan umat-Nya.

Teologi Reformed menjunjung tinggi otoritas Alkitab sehingga semua hukum Allah dipelajari dengan teliti dan mendalam. Berbeda dengan utilitarianisme Fletcher yang menghalalkan metode demi tercapainya tujuan, teologi Reformed menyatakan bahwa perbuatan baik harus memiliki tiga hal yaitu motivasi yang benar, cara yang benar sesuai standar Firman Tuhan, dan tujuan yang benar yaitu kemuliaan Allah. Utilitarianisme Fletcher mengasumsikan bahwa manusia dengan kuasanya dapat menentukan hasil akhir dari tindakannya, tetapi teologi Reformed mengakui bahwa Allah-lah yang berdaulat penuh. Teologi Reformed juga menekankan topik kekudusan. Ketika Fletcher berkata "sin bravely", teologi Reformed berbicara mengenai "Mortification of Sin". Fletcher membiarkan kaum situasionis hidup dalam ambiguitas dan dosa, tetapi teologi Reformed percaya akan kejelasan dan keabsolutan panduan Firman Tuhan, menjauhi dosa, dan 
mengejar kesempurnaan karena Allah memerintahkan demikian. Fletcher menjelaskan kasih secara abstrak berdasarkan pemikirannya sendiri, tetapi teologi Reformed mendefinisikan kasih sebagaimana seluruh bagian Alkitab nyatakan. Fletcher mengusulkan etika yang antroposentris, yaitu kebaikan sesama sebagai summum bonum, tetapi teologi Reformed menyatakan bahwa kemuliaan Allah adalah prioritas yang tertinggi.

Jika teori etika situasi Fletcher diterapkan di Indonesia, maka para penganut agama minoritas akan tersisih dan tidak mendapatkan banyak perhatian serta dukungan pemerintah. Ini karena Fletcher menyatakan bahwa kasih harus mementingkan mayoritas. Teori etika situasi Fletcher membuat hukum dan penegakkan hukum dalam negara atau institusi apapun menjadi ambigu. Maka dari itu, dapat disimpulkan bahwa teorinya tidak bisa diterapkan dan dipraktikkan. 